\title{
THE EUROPEAN PARLIAMENT ELECTIONS AND CZECH POLITICAL PARTIES: MUCH ADO ABOUT NOTHING? ${ }^{1}$
}

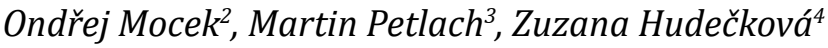

\begin{abstract}
The paper inquires divergences in electoral programs of four Czech political parties (the ČSSD, KDU-ČSL, KSČM, and the ODS) as delivered for all the previous European Parliament elections. The aim of this study is to compare the use of national and European themes as delineated in programs. It is assumed that, in many cases, the programs contain topics and aspects which are specific and valid for elections on the national level instead. Thus, the paper elaborates on one of the characteristics of the second-order elections theory as exemplified in the Euro-elections. Results of the analysis showed a significant superiority of national affairs over the European issues in the examined samples. Although the number of political parties varies in individual periods, the study has also confirmed the assumption drawn from the theory of second-order elections. Therefore, political parties utilize political programs for the European Parliament elections as of national interest with domestic affairs, not European. Furthermore, the study considers dissimilarities among political parties in positive and negative attitudes toward the EU. Hence, sundry approaches to European affairs may be identified across the Czech political parties.
\end{abstract}

KEY WORDS: European Union, European Parliament elections, Election programs, Czechia, Political parties, Euroscepticism.

\section{INTRODUCTION}

The European Parliament (EP) may be dated back to 1952. However, the initial form of delegates grouping to represent the Member States

\footnotetext{
1 This article has been supported by the research grant No. FRRMS-IGA_2016/023: "The Cohesion of Political Groups in the European Parliament with Regard to Regional Development" and by the Czech Science Foundation project No. GA20-07592S): "Hey, Slavs! The visual culture of propaganda inspired by Slavic nationalisms in the Czech Republic and Slovakia and its anti-European character".

${ }^{2}$ Faculty of Regional Development and International Studies Mendel, University in Brno, Tř. Generála Píky 7, Brno, Czech Republic, Email: mocek@mendelu.cz.

${ }^{3}$ Faculty of Regional Development and International Studies, Mendel University in Brno, Tř. Generála Píky 7, Brno, Czech Republic, Email: martin.petlach@mendelu.cz

${ }^{4}$ Faculty of Regional Development and International Studies, Mendel University in Brno, Tř. Generála Píky 7, Brno, Czech Republic, Email: z.hudeckova@gmail.com.
} 
parliaments and having a mere consultative function has experienced a considerable development (Blondel, Sinnott, Svensson, 1998). Currently, the appearance is given by the Treaty of Lisbon. The European Parliament represents the European Union (EU), and together with the Council it accounts for decision-making procedures. Its powers are visible in the legislative, budgetary, and control policies as an unparalleled "hybrid model" (Hix, Noury, Roland, 2007, 13). The change embodied in the aforementioned Treaty of Lisbon has not only strengthened the EP's position due to increasing powers, but even modified its composition (Terpan, Saurugger, 2019).

In 1979, the very first direct election to the European Parliament was held. Yet, the electoral system has not been unified in the form, since it still consists of common electoral procedures and specific provisions of the Member States. And on a long-term basis, the EP's role has been perceived as "week" (Norris, 1999, 86), notwithstanding the EP's increase of involvement in international affairs (Stavridis, Irrera, 2015). The European Parliament election, known as the Euro-election, takes place every five years, and the Czech Republic held the first election of this type in 2004. In addition, the topicality of Euro-elections in respect of the polling in 2019 has been accompanied and intensified by a seriously increased lack of concern for European affairs as evident in the case of the Czech Republic (Ferebauer, 2018).

The theory of second-order elections had been coined by Karlheinz Reif and Herman Schmitt (1980). They defined different particularities of national parliamentary elections and the elections to the EP. The term already prompts that second-order elections are interpreted as less germane in comparison with the first-order elections, i.e. elections to national parliaments. Subsequently, the theory has been proved to be relevant and valid for the EP elections, despite the divergences occurring in each Member State (Marsh, 1998). One of the main scholars inquiring and applying the theory of second-order elections in the Czech Republic is Šaradín (2008). Although the inclusion of the European elections within the group of second-order elections may not be flattering, and it highlights a lower importance of the EP, it would be false to omit this institution due to the growing powers in the structural scheme of the European Union. The theorists studying the second-order elections perceive a relevance of this type of elections in connection with the first-order elections and thus the possibility to observe new political parties, test the voters' base and its size, and the popularity of political parties and its leaders in a general sense with 
the voters (ibid., 11-46). Among certain characteristics of second-order elections with regard to the European Parliament, these are as follows: a significantly lower turnout, ${ }^{5}$ election programs and campaigns have a largely stressed national basis, slightly higher percentages of invalid votes, the governing party may also lose the voters' support (as in midterms), and voters' final say is usually being influenced by the main personalities in campaigns rather than any partisan affiliations. Having acknowledged the multifarious facets of Euro-elections and Europeanization and its impact on political parties before the accession to the EU (e.g., Leška, 2015), a certain lack of analyses dedicated to political parties and corresponding policies after joining the EU have endured, especially in case of Central and Eastern Europe (CEE).

Hence, this article analyzes election programs of selected Czech political parties that had previously gained at least one mandate in all of four previous elections to the European Parliament. Thus, the programs for elections of 2004, 2009, 2014, and 2019 will be compared. ${ }^{6}$ The study focuses strictly on distinction of relevant and thus entrenched parties in the Czech party system. Consequently, the EP elections in connection with other niche or brand-new parties shall be then examined separately (cf., e.g., Maškarinec, 2017). This sine qua non condition persists in accord with the findings of Marsh (1998) who accentuated the significance of reciprocal alterations between the opposition and party in power in respect of the EP. Yet the findings may be to avail nowadays because both the opposition and ruling parties may draw on them. On the whole, the purport is to measure and state the differences between the use of national and European themes in the EP election programs within examined periods. It is expected that the EP election programs may include topics that are typical for the elections on the national level. As depicted in the theory of second-order elections in Central and Eastern Europe (Stoyanov, 2017, 114-117), the themes emphasize national, meaning domestic, themes, and thus other spheres are being overshadowed. Even though this theory has already been questioned and applied for the Czech party system in regard

\footnotetext{
${ }^{5}$ Slovakia and the Czech Republic exhibited the lowest turnout rates in the 2014 European Parliament election, making 18.2 and $13.05 \%$ respectively (European Parliament, 2018). Therefore, first and foremost, this initial indicator exemplifies the situation greatly.

${ }^{6}$ At least four other parties, the ANO (The YES Party), TOP 09, Piráti (Czech Pirate Party), and the SPD, Svoboda a prímá demokracie (Freedom and Direct Democracy) may bias the analysis due to the fact that these are not fixed as a "relevant party" in a traditional sense, and in addition, they contradict the prerequisites for the theory of second-order election in case of EP.
} 
to the European elections (Havlík, 2009; Kovář, 2014), they are outdated and were not able to employ any diachronic comparisons, nor elaborated on the programs' content in respect of its affirmative or negative attitudes toward the European Union.

This text follows and applies the theory of second-order elections while examining the topics covered in the election programs to demonstrate and measure sundry differences between the use and utilization of national and European affairs in the election programs to the European Parliament, so that the end of "honeymoon period" may be adverted to (Šaradín, 2008; Šimunjak, Milanović, 2017). The research question to be answered, thus, stands and asks: To what extent are the election programs of selected Czech political parties engaged in European issues for the elections to the European Parliament? Thereupon, after discussing research methods as employed in this paper, separate analyses are to be delivered for examined parties. In the aftermath, the programs and the use of national versus European topics will be compared. Finally, the concluding section considers whether the orientation of given parties tends to be positive or negative toward the EU. In the last part, the article elaborates on a generally accepted assertion (e.g., Nielsen, Franklin, 2017; Wring, Grill et al., 2017), according to which Euroscepticism (or so called "Eurorealism" as claimed from within) has prevailed since the 2014 EP election. In this text, nevertheless, mere indicators as public attitudes toward the European Commission and the EU membership itself are not to be taken into account. Instead, the analysis bears in mind the top-down approach when examining a possible attitude shift among political parties.

\section{METHODOLOGICAL REQUISITES}

From a vast range of programs for the elections to the European Parliament, four Czech political parties were sampled. The key requisite was based on achieving a minimum of one mandate in all of the four previous elections to the EP. Hitherto, four Euro-elections (2004, 2009, 2014, and 2019) were held and will be inquired. The reason endorsing this criterion lies in the eventuality to assess the programs of parties that succeeded, i.e. addressed the voters in success. At the same time, the analysis seeks to track gradual development trends of European issues in the election programs, and it implies that only successful parties may be of great value to analyze. Selected parties are as follows: the Christian and Democratic Union Czechoslovak People's Party (KDU-ČSL), the Communist Party of Bohemia 
and Moravia (KSČM), Civic Democratic Party (ODS), and the Czech Social Democratic Party (ČSSD).

The texts of election programs will be subject to a content analysis. As a research method, it is one of the eldest approaches in social sciences. It has obtained its recognition in the late 1940s, and as a method, it has been used for analyses of media messages in political communication (Krippendorff, 2004). The main advantage of the content analysis is the conversion of texts into a quantitative description of examined content and a consequent utilization in numerical terms. The most crucial step, however, is to divide the text into analytical units which are predetermined in accordance with the encoding scheme (Drisko, Maschi, 2015). For the text encoding, the polling scheme of Comparative Manifesto Project (CMP) will be employed as the most comprehensive tool. ${ }^{7}$ The encoding scheme is based on mapping assorted political issues. Moreover, these are classified into seven thematic areas aggregating the total of 56 index values (CMP, 2011).

Nonetheless, this approach remains afflicted by certain limits one must bear in mind (cf., e.g., Weber, 1990). First and foremost, this kind of research may be repeated, but subjective biases in encoding may cause indirect conflict of interest or inaccuracies. More specifically, this problem arises in sentence units stressing ambiguous information. Another limitation is to consider a broad diversity of election programs and the lack of any unified processing arrangements. Furthermore, programs vary conspicuously in length, forms, and structures. The content is indeed affected by given social and political environment and political culture each country possesses on different levels.

\section{RESEARCH FRAMEWORKS}

Initially, the full texts of election programs had to be acquired in order to avoid any confusion and misunderstanding and due to its future availability. The subsequent content analysis split the programs into units, i.e. sentences in this case. For the purposes of preliminary analytical research, no titles and lists of content of election programs were taken into account. Analytical units were then encoded in accordance with the scheme of Comparative Manifesto Project (CMP) ${ }^{8}$. This method has been utilized as a means to

\footnotetext{
${ }^{7}$ Other approaches may be observed, Ringe (2010) has applied his own coding scheme while examining the European Parliament.

${ }^{8}$ This method does not serve as the only possible application of quantitative content analysis. The authors indicate the possibility of using the computer software of Wordscores. The
} 
investigate European issues in political programs (e.g., Somer-Topcu, Zar, 2014). In the Czech academic milieu, the pioneering work of this methods may be attributed to Mansfeldová (2003), ${ }^{9}$ followed by Eibl (2011) who has elaborated on the matter in his book.

The CMP encoding scheme consists of seven thematic areas covering 56 categories of index values. These areas are as follows: (1) foreign relations; (2) freedom and democracy; (3) political system; (4) economy; (5) welfare and quality of life; (6) social organization; and (7) social groups. If the political expression on any subject is negative, it is necessary to state, however, that this particular topic still endures as relevant (Procházková, Hloušek, 2013).

The margin of categories remains universal. They are designed in order to allow the analytical units to be assigned. If an analytical unit fits into two categories, the CMP precepts are being applied. It works similarly if an analytical unit cannot be assigned into any of categories. Thus, these units were encoded under the code of 000, implying any statement without content (Eibl, 2011, 86-92).

The CMP offers mapping of all the political issues occurring in election programs. For this paper, though it is not relevant to map every separate index value occurring in programs. Instead, only analytical units focusing on European integration are to be emphasized. For the purposes of analysis, individual aggregate index values were generalized, including seven themes, thereby achieving a simplified resultant of data matrix. Table 1 clearly shows the themes and values of aggregated index.

Table 1: Content analysis of individual topics and its expressions

\begin{tabular}{|c|c|c|}
\hline Theme & $\begin{array}{c}\text { Numeric } \\
\text { designation }\end{array}$ & $\begin{array}{c}\text { The content of political communication in } \\
\text { the aggregate index value }\end{array}$ \\
\hline $\begin{array}{l}\text { Foreign } \\
\text { relations }\end{array}$ & 100 & $\begin{array}{c}101 \text { Foreign relations: positive, } 102 \text { Foreign } \\
\text { Relations: negative } 103 \text { Anti-imperialism, } 104 \\
\text { Military: positive, } 105 \text { Military: negative, } 106 \\
\text { Peace } 107 \text { Internationalism: positive, } 108 \\
\text { European Community / Union: positive, } 109 \\
\text { Internationalism: negative } 110 \text { European Com- } \\
\text { munity / Union: negative }\end{array}$ \\
\hline
\end{tabular}

technique, however, is far criticized in the Czech Republic due to application difficulties for the Czech morphology.

${ }^{9}$ Mansfeldová (2003) elaborated on the method while using an instance of political parties in the Czech Republic at the Second Congress of Czech Political Scientists. 


\begin{tabular}{|c|c|c|}
\hline $\begin{array}{l}\text { Freedom } \\
\text { and de- } \\
\text { mocracy }\end{array}$ & 200 & $\begin{array}{l}201 \text { Freedom and Human Rights, Democracy } \\
\text { 202, } 203 \text { Constitutionalism: positive, } 204 \text { Con- } \\
\text { stitutionalism: negative }\end{array}$ \\
\hline $\begin{array}{l}\text { Political } \\
\text { system }\end{array}$ & 300 & $\begin{array}{c}301 \text { Federalism, centralism 302, } 303 \text { Efficiency } \\
\text { of bureaucratic apparatus 304 Corruption } 305 \\
\text { Political Authority }\end{array}$ \\
\hline Economy & 400 & $\begin{array}{l}01 \text { Free Market, } 402 \text { Initiatives, } 403 \text { Market } \\
\text { regulation } 404 \text { Economic Planning, } 405 \text { Cor- } \\
\text { poration, } 406 \text { Protectionism: positive, } 407 \text { : } \\
\text { Protectionism: negative } 408 \text { Economic goals, } \\
409 \text { Keynesian tactic } 410 \text { Economic Growth: Po- } \\
\text { sitive } 411 \text { Technology and Infrastructure, } 412 \\
\text { State controlled market, nationalizations } 413 \text {, } \\
414 \text { Economic orthodoxy, } 415 \text { Marxist theory: } \\
\text { positive, } 416 \text { Sluggish economy }\end{array}$ \\
\hline $\begin{array}{l}\text { Welfare and } \\
\text { quality of } \\
\text { life }\end{array}$ & 500 & $\begin{array}{c}501 \text { Environmental Protection, } 502 \text { Culture: } \\
\text { positive, } 503 \text { Equality: positive, } 504 \text { Growing } \\
\text { welfare state, the welfare state limits 505, } 506 \\
\text { Rising educational system, educational system } \\
\text { 507 Limits }\end{array}$ \\
\hline $\begin{array}{l}\text { Social orga- } \\
\text { nization }\end{array}$ & 600 & $\begin{array}{c}601 \text { National Way: positive, } 602 \text { National Way: } \\
\text { negative } 603 \text { Tradition and morality: positive, } \\
604 \text { Tradition and morality: negative } 605 \text { Law } \\
\text { and Order: positive, } 606 \text { Civic attitudes: positi- } \\
\text { ve, } 607 \text { Multiculturalism: positive, } 608 \text { Multicul- } \\
\text { turalism: negative }\end{array}$ \\
\hline $\begin{array}{l}\text { Social } \\
\text { groups }\end{array}$ & 700 & $\begin{array}{c}701 \text { Working groups: positive, } 702 \text { Working } \\
\text { groups: negative, } 703 \text { Agriculture and rural } \\
\text { development: positive, } 704 \text { Central Avenue, } \\
705 \text { Disadvantaged groups } 706 \text { Economically } \\
\text { inactive group }\end{array}$ \\
\hline $\begin{array}{l}\text { Without } \\
\text { content }\end{array}$ & 000 & Statements without content \\
\hline
\end{tabular}

Source: Authors, in accordance with the CMP (2011).

To answer the research question, national and European topics were compared in accordance with the analysis results for electoral issues within investigated periods. Specifically, the detected index values have been assigned to two groups: (1) national, and (2) European topics. National themes represent affairs directly related to the internal politics of the Czech Republic. Among the examples of index values, there are the themes as follows: freedom and democracy, political system, economy, prosperity and quality of life, social order and social groups. It is such communication 
content of sentences expressing the functioning of the state, institutional structure, and national policy. These communications are primary issues for the first-order elections. The topics include political expressions directly related to the agenda of the European Union, ranking the index values of the code of 108 of the European Community / European Union: positive and the code of 110 of the European Community / European Union: negative.

From the 2004 election, following programs are to be analyzed:

- KDU-ČSL: European election program;

- KSČM: For you, with you: At home and in the EU;

- ODS: Blue chance for Europe, the same chance for everyone;

- ČSSD: Europe: Right for people.

From the 2009 election, following programs are to be analyzed:

- KDU-ČSL: Election program for the 2009 election to the European Parliament;

- KSČM: Open election program for the 2009 election to the European Parliament;

- ODS: ODS.EU - Election program, 2009;

- ČSSD: Guarantee: The program for 2009.

From the 2014 election, following programs are to be analyzed:

- KDU-ČSL: KDU-ČSL election program for the election to the European Parliament: $23^{\text {rd }}$ and $24^{\text {th }}$ May 2014;

- KSČM: KSČM election program for the 2014 election to the European Parliament;

- ODS: Turning the EU the right direction;

- ČSSD: Together in Europe.

For the 2019 election, following programs are to be analyzed:

- KDU-ČSL: For a better Europe;

- KSČM: Let's not let it be;

- ODS: We are the heart of Europe, and we want to be heard;

- ČSSD: For a fair Europe.

\section{AN OMNIBUS OF FINDINGS}

Results of analyses for national and European issues in the election programs for given periods are initially compared within individual political 
parties. Each section is subsequently concluded and depicted in a graph as the use of sentence units, covered by the index of 108, European Union: positive and 110, European Union: negative, were examined and compared. The coding results for the election programs and clusters, based on national and European themes, are showed in the following charts. The bar graph comparing national and European themes is divided into four periods of elections in 2004, 2009, 2014, and 2019. The line chart, on the other hand, shows two types of coded indexes in the European integration, thus the index of 108, European Union: positive and 110, European Union: negative.

\subsection{European election programs and the KSČM}

The KSČM election programs had a relatively similar number of coded sentence units in all examined periods (175 in 2004, 105 in 2009, 239 in 2014, and 126 in 2019). In all given elections, national themes prevailed in the KSČM's programs, of which 504 indexes were dominated by the growing welfare state, 601, National Way: positive, 701, working groups: positive and 501, Environmental protection. A percentage distribution of European topics ranged from $13.7 \%$ in 2004 to over $22.8 \%$ in 2009, $24.3 \%$ in 2014, up to $30.1 \%$ in 2019. Thus, the share of European issues in the election programs experienced a slow increase when the peak figure representing European themes escalated in the latest Euro-election. In comparison to national issues, however, the EU represented only about one-third of the data. The sentence units referring to the European integration in 2004 and 2014 has been encoded with a predominance of the index of 108, European Union: positive. In 2009, though, the ratio of the index of 108, European Union: positive and 110, European Union: a negative turned to be equalized. From a long-term perspective, though, a higher level of European issues emphasized in the program also signifies a gradual rise in negative stances of KSČM. 
Graph 1: The share of European and national themes in the programs of KSČM

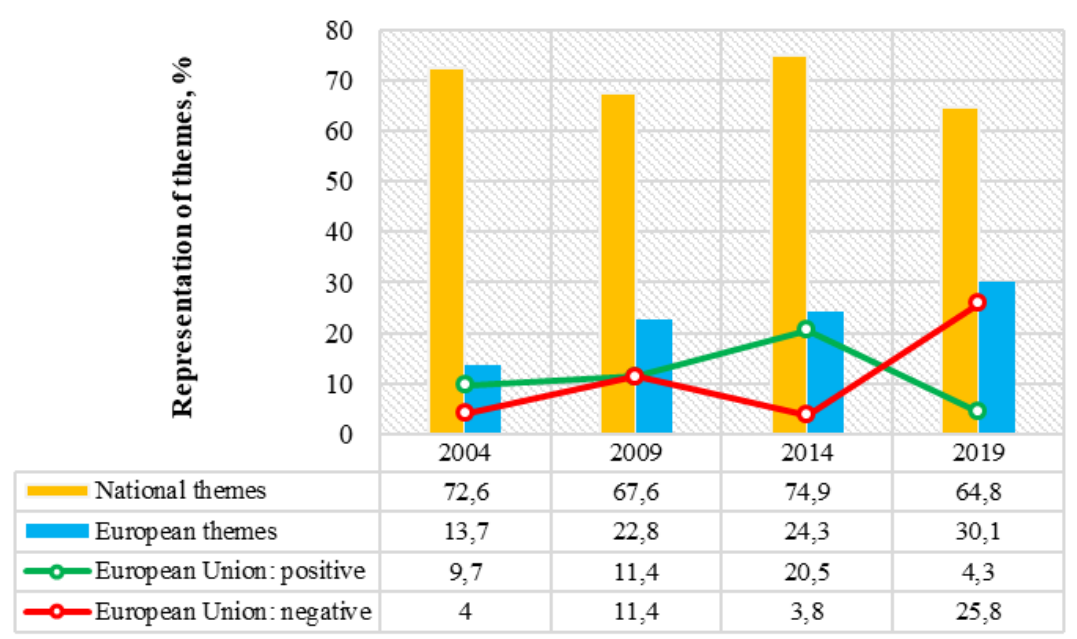

Source: Authors

Positive statements toward the European integration were related to general support, benefits of labor mobility and grants, support of integration in human rights and freedoms, and until 2014 even asylum and migration policy was included. In the programs, the KSČM also expressed sympathy for strengthening the powers of the European Parliament, and the consequent establishment of single financial frameworks. On the contrary, as shown in the Graph 1, negative appraisals were observed and appeared within the issue of market interconnection, followed by criticism of bureaucracy, and negative interferences enlarging social differences.

\subsection{European election programs and the KDU-ČSL}

Election programs of KDU-ČSL have exhibited alike numbers of coded sentence units in given periods, namely 235, 313, 168, and 122 in the corresponding programs of 2004, 2009, 2014, and 2019. Bar Graph 2 shows the share of national and European issues taking place in all electoral periods. It is evident that there is a significant excess of percentage in respect of national issues. Their share ranged from $74.5 \%$ in 2004, over $77.9 \%$ in 2009 , to $80.9 \%$ in 2014 . Afterwards, the 2019 European election has brought a minor change, since the occurrence of European topics nearly equalized the national ones. The highest indices shifting to national topics 
included indexes of 603, Traditions, values and family, and 403, Market regulation.

The European topics reached the highest percentage in the first election period, in 2004, making the total of $20.4 \%$. In the second period, the share of representation lowered by almost half and reached $9.2 \%$. The penultimate electoral period was filled with European themes by $17.3 \%$ in 2014, and for the 2019 election, the program almost doubled in the European agenda, making $35.3 \%$. Topics of the European integration had been used mainly in positive messages. Single sentence units referring to the index of 110 , European Union: negative, were coded only in the 2004 election. These statements had been meant to protect the domestic market and consumers in particular. Remarkably, in the ultimate European election that was held in 2019, the party has added European themes significantly that they have almost dominated. However, at the same time, there is a noticeable increase in negative and critical attitudes toward the EU, while the positive attitudes were kept steady. In the 2019 election, the levels of positive and negative stances of ca $15+\%$ tend to linger on the original positive values of this party in 2004 . Expressing a positive attitude toward the European integration, as coded under the index of 108, European Union: positive, has been fundamentally based on shared values for the European integration, solidarity, support and vision of the common currency of the EU as the security arbiter.

Graph 2: The share of themes in the programs of KDU-ČSL

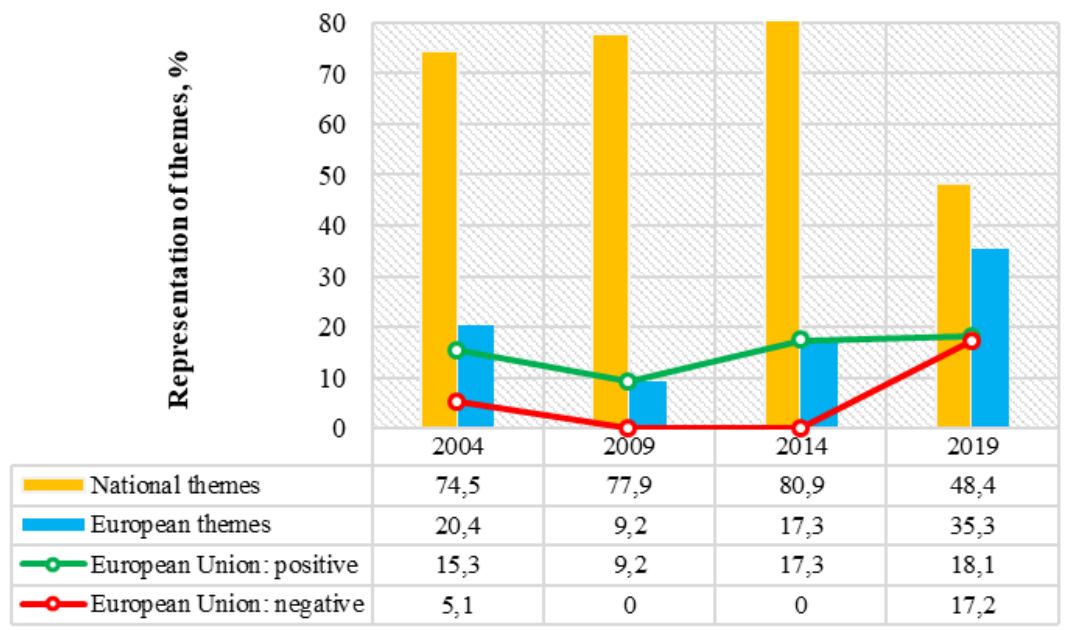

Source: Authors 


\subsection{European election programs and the ČSSD: Two extremes}

The number of coded sentence units of election programs of ČSSD boasts about two firsts, and that of a minimal number of 85 for sentence units in 2014 and 1,043, meaning the highest number of sentence units, in 2009. In the 2004 and 2019 election programs, the ČSSD adopted 123 and 462 sentence units respectively. The share of employed national and European themes is depicted in Graph 3. In each year of election periods, the national themes reached a higher share. The tightest share of topics took place in 2014 , since $55.3 \%$ of national themes and $41.2 \%$ of European themes were observed. In the first two electoral periods, national themes accounted for a two-third superiority as obvious from the data when it reached $62.6 \%$ in 2004 and $76.3 \%$ in 2009 . National themes were most frequently coded to indexes of 504, Growing social state, and 403, Market regulation.

In the first two programs, the European integration had been interpreted only by the index of 108, European Union: positive. In the first period, European themes represented $28.5 \%$ of the share, and in the following period, it was only $14.3 \%$. In the third one, sentence units referring to the index of 110, European Union: negative, appeared, too. In 2014, 41.2 $\%$ of European themes share had $4.7 \%$ sentence units coded in the index of 110, European Union: negative. In the communication index of 108, European Union: positive, the ČSSD supported the adoption of the common currency, the Treaty of Lisbon, and immigration policy, all of which the party questioned in the 2019 European election program. Interestingly enough, the ČSSD remains the only party that has been avoiding strong criticism and negative comments in regard to the EU. Nevertheless, when analyzing the party's support and positive attitudes, there is a certain divergency among inquired years when the ČSSD had to adjust its rhetoric accordingly. 
Graph 3: The share of European and national themes in the programs of $\check{C S S D}$

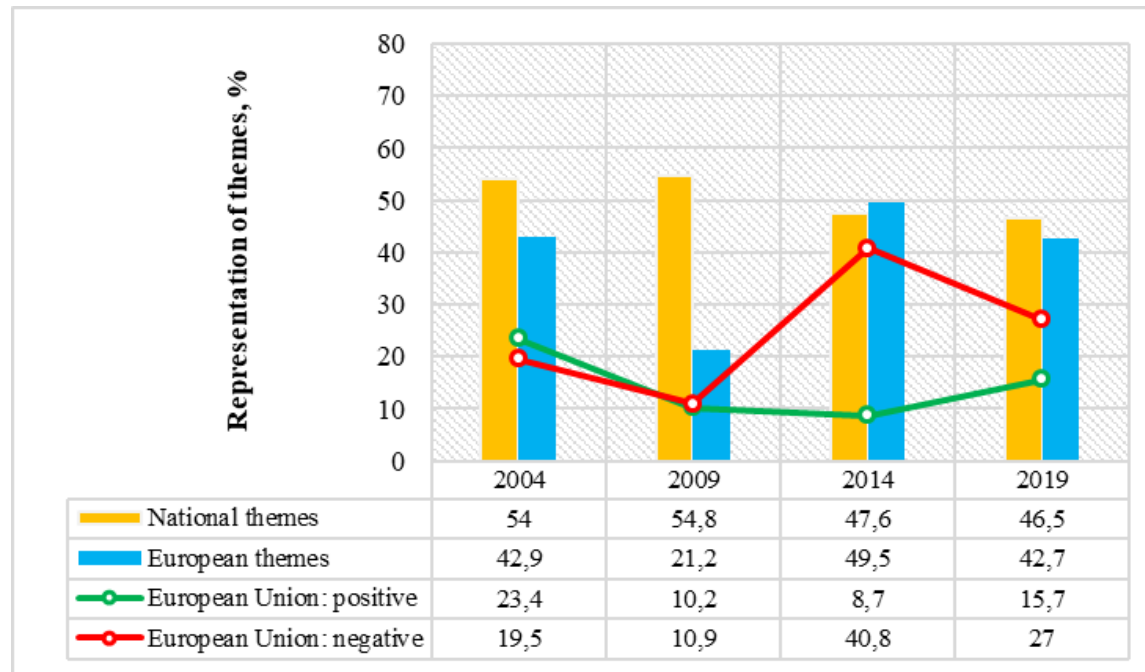

Source: Authors

Overall, the European Union has been seen as a security guarantor and the biggest economic and labor market in the world. The index of 110, European Union: negative, considered especially the bureaucratic aspect of the European Union, together with its criticisms of inefficiency and wasteful costs. Last but not least, in comparison to other examined parties, the ČSSD was the only party to stick interchangeably to the appellation "Europe" for addressing the organization, not the European Union as conventional when bearing in mind other political parties.

\subsection{European election programs and the ODS: As you like it}

The sum of sentence units in the ODS election programs in 2004, 2014 and 2019 remains very similar, 103, 128, and 174 respectively. The year of 2009 was rather different whilst the total of 586 sentence units was to be found. The election program of that year was specific too regarding the share of national and European themes as depicted in Graph 4. Compared to 2004, 2014 and 2019 wherein the share was similar, while in 2004, there was a $54 \%$ representation of national themes and $42.9 \%$ of European issues, in 2014, it was $47.6 \%$ of national themes and $49.5 \%$ of European ones, in 2019, it was $46.5 \%$ of national themes and $42.7 \%$ of European 
ones, the year of 2009 had a $54.8 \%$ share of national issues and $21.2 \%$ of European themes. The ODS has been a party achieving the most dominant representation of European themes to the detriment of national issues.

The second aspect shown in this graph is the representation share of indexes 108, European Union: positive and 110, European Union: negative. The proportion was specific per each year. In 2004, the index of 108, European Union: positive prevailed with a $23.4 \%$ share to a $19.5 \%$ share of index of 110, European Union negative. In 2009, these shares turned to be almost balanced, and there was only a $0.7 \%$ superiority of index of 110 , European Union: negative. In 2014, there was a crucial increase in sentence units referring within the index of 110, European Union: negative with prevalence up to $32.1 \%$ at the expense of the index of 108, European Union: positive.

Negative attitudes toward the European integration keeps overlapping among all the studied periods. The ODS represents an oppositional stance toward federal mechanisms of the European integration, common currency, and the fiscal and banking union systems. The ODS's communication was delivered with an aim to be positive due to the economic benefits resulting from the membership itself. Therefore, the European Union has been perceived and presented as a free-market, security, and energy selfsufficiency means. National themes were employed primarily in sentence units referring to the indexes of 601, National Way: positive; 408, Economic goals; and 401, Free market. The sentence units have mirrored in the characteristics of the party, i.e. a strongly Euro-realistic mentality and economic foci. 
Graph 4: The share of European and national themes in the programs of ODS

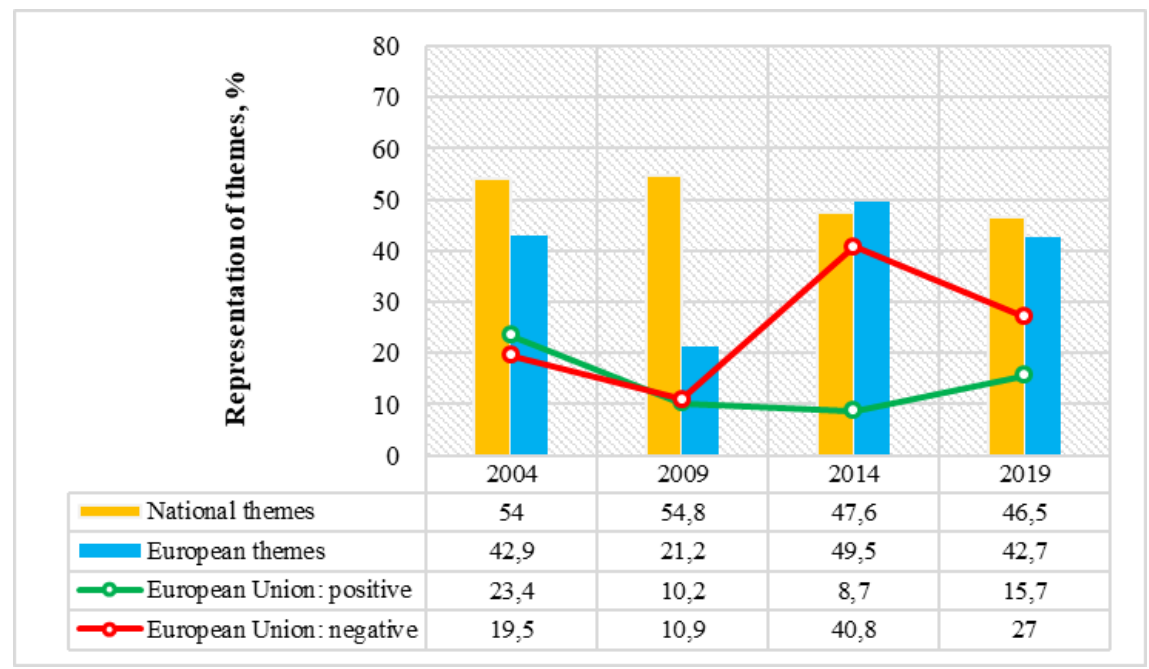

Source: Authors

\section{NON-EUROPEAN PARTIES IN THE EURO-ELECTIONS?}

This section compares achieved percentage values of European and national themes and its shares. The results are shown in Graph 5. For each period, there are four columns identified, marking the shares of topics selected for the examined political parties. The columns are divided into two parts characterizing two groups of analyzed topics: national and European ones. The data does not necessarily reach the level of $100 \%$ due the index of 000 , without content, of which data has not been included. In selected election programs, a higher proportion of national topics may be identified in comparison with European issues. The most striking results are distinctive within the ODS in 2014, followed by the year of 2004, and then in case of ČSSD in 2014. At the same time, the 2019 Euro-election vindicated the trend continuation pattern of incremental rise in European issues among the programs of all examined parties. Yet the national themes still dominate. 
Graph 5: Representation shares of European and national issues in the programs, in \%

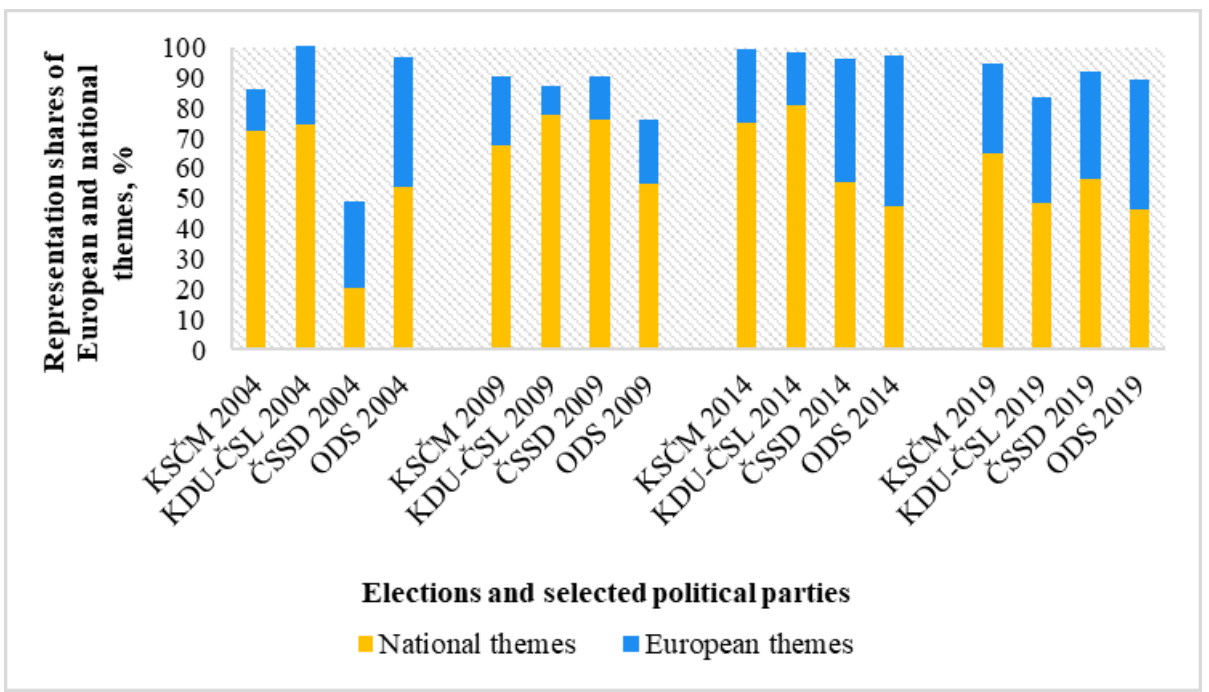

Source: Authors

The list of individual results is shown in Table 2. For each period, there are individual results of percentage shares listed into sentence units belonging to the group either of national or European character. In the election programs, the parties used, on the average, $65.9 \%$ of national themes and $26.4 \%$ of European themes in 2004. In the next election, for these indicators, values of $69.15 \%$ for national issues and $16.9 \%$ of European issues were obtained. In the 2014 election programs, $64.7 \%$ of sentence units referring to national issues and $33.1 \%$ to European issues may be ascertained. For the 2019 European elections, the party programs consisted of $35.8 \%$ of European issues. These figures advert to volatility and instability of European topics in election programs which may be mirrored in the Czech party system as a whole (see, Linek, Lyons, 2014).

Furthermore, the table also highlights four major ratios of themes in the election programs in which the values are numerically close. These are the election program of ODS from 2004, 2014 and 2019, and ČSSD's program from 2014 which are characterized by evenness. In juxtaposition to changes taking place among the parties, the KSČM maintains its constant line of figures. Based on the interim findings from the election programs and the overall summary of results, it is possible to confirm the assumption that the 
election programs of selected political parties in elections to the European Parliament contain more of national themes with no connection to the EP, and which are rather associated with elections to the Czech national parliament, thus representing the first-order elections. Similarly, as in other countries that had joined the EU recently, the honeymoon period with the EU has ceased to exist (Šimunjak, Milanović, 2017, 164) even though the electoral programs still possess the European topics, indeed, only the elements of criticism have been adjusted.

Table 2: Shares of national and European themes in election programs, in \%

\begin{tabular}{|c|c|c|c|c|c|c|c|c|}
\hline \multirow[b]{2}{*}{ 胥 } & \multicolumn{2}{|c|}{2004} & \multicolumn{2}{|c|}{2009} & \multicolumn{2}{|c|}{2014} & \multicolumn{2}{|c|}{2019} \\
\hline & 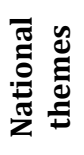 & 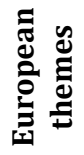 & 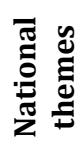 & 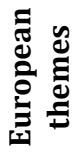 & 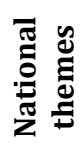 & 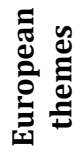 & 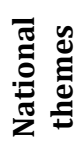 & 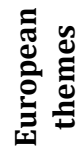 \\
\hline KSČM & 72.6 & 13.7 & 67.6 & 22.8 & 74.9 & 24.3 & 64.8 & 30.1 \\
\hline KDU-ČSL & 74.5 & 62.6 & 77.9 & 9.2 & 80.9 & 17.3 & 48.4 & 35.3 \\
\hline ČSSD & 20.4 & 28.5 & 76.3 & 14.3 & 55.3 & 41.2 & 56.7 & 35.2 \\
\hline ODS & 54.0 & 42.9 & 54.8 & 21.2 & 47.6 & 49.5 & 46.5 & 42.7 \\
\hline
\end{tabular}

Source: Authors

The only exception in which the preponderance of sentence units belonging to European issues, lies in the election program of ODS from 2014. In this instances, European issues are outweighing national issues by $1.9 \%$. Inquiring the results of elections to the European Parliament thus, together with the content of election programs, manifested that this paper's findings are therefore in line with the second-order elections theory as well.

\subsection{Positive or negative attitudes toward the EU?}

The last section of this paper takes into consideration the communication of sentence units within the group of European themes. Table 3 shows a simplified overview of applied communication on the European integration in positive and negative terms. 
Table 3: An overview of coded indexes of positive and negative attitudes in the examined election programs, in \%

\begin{tabular}{|c|c|c|c|c|c|c|c|c|}
\hline \multirow[b]{2}{*}{$\underset{0}{\overrightarrow{0}}$} & \multicolumn{2}{|c|}{2004} & \multicolumn{2}{|c|}{2009} & \multicolumn{2}{|c|}{2014} & \multicolumn{2}{|c|}{2019} \\
\hline & 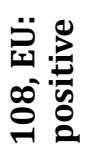 & 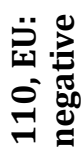 & 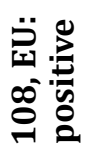 & 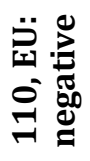 & 总 & 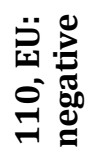 & 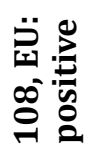 & 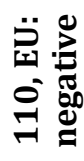 \\
\hline KSČM & 9.7 & 4.0 & 11.4 & 11.4 & 20.5 & 3.8 & 4.3 & 25.8 \\
\hline $\begin{array}{l}\text { KDU- } \\
\text {-ČSL }\end{array}$ & 15.3 & 5.1 & 9.2 & 0.0 & 17.3 & 0.0 & 18.1 & 17.2 \\
\hline ČSSD & 28.5 & 0.0 & 14.3 & 0.0 & 36.5 & 4.7 & 31.6 & 3.6 \\
\hline ODS & 23.4 & 19.5 & 10.2 & 10.9 & 8.7 & 40.8 & 15.7 & 27.0 \\
\hline
\end{tabular}

Source: Authors

The ratio of sentence units coded under the index of 108, European Union: positive prevailed in a vast majority of election programs. The exception was found in the election program of KSČM from 2009 when the ratio of the use of sentence units tended to be even. Sentence units under the index of 110, European Union: negative have significantly prevailed in the ODS election programs from 2009 up to 2019. Most crucially, in 2009, there was a dominance of $0.7 \%$ and of $32.1 \%$ in 2014, and the preponderant figure has endured by a $11.3 \%$ difference in 2019. The complete absence of sentence units under the index of 110, European Union: negative has occurred in the election programs of the KDU-ČSL since the party did not use any sentence units under this index in 2009, nor in 2014. In the election programs of ČSSD, this index was not employed in 2004 and 2009, either. In a sweeping, yet cursory, analysis of Marinescu et al. $(2017,143)$, CEE manifested a "neutral representation" of the EU in the prior campaign in 2014.

On the whole, the content-sentence units were used either in texts of general support toward the European integration and its shared values or, on the contrary, sentence units expressed stances against federal mechanisms. In the second variant, the sentence units reflected predominantly the current topics, such as the economic crisis, energy security, common currency, common market, labor mobility, and bureaucracy. Therefore, and to no amazement, an accrual of initial waves of populism had already occurred in the 2004 EP election and its aftermath (Auers, 2005, 754) signifying a snap reappraisal of relations with the EU with a populist peak which was yet to come later in 2014. 


\section{CONCLUSION}

The research sample considered the programs of four selected Czech political parties in elections to the European Parliament. In the 2004 EP election, the programs parties had used, on the average, consisted of 65.9 $\%$ of national themes and $26.4 \%$ of European ones. For 2009, the ratio of national themes was additionally (3.25\%) higher than in the previous election. National themes were used, on the average, in $69.15 \%$ of the election programs. The European themes only had a 16.9\% representation in 2009. Even though the penultimate and latest election, held in 2014 and 2019 , experienced the highest amount of representation of European themes in the election programs (33 \% and $35.8 \%$ ), it was still less in comparison with the national issues and its use in the programs.

An even representation share of national and European themes was observed in the programs of ODS and ČSSD. Interestingly, both the averaged values and individual analyses of election programs showed that the representation of EU sentence units had been reduced in 2009 as previously declared by Kovář (2014), but it increased in 2014 and 2019 again. This phenomenon may be attributed to the then unstable political situation in the Czech Republic. A few months before the 2009 election to the European Parliament, the Czech Prime Minister was toppled, and a caretaker government had to be formed. All of this happened in the course when the country presided the Council of the EU from January 2009. In line with Stoyanov (2017), political parties focused on domestic affairs rather than the EU as a whole. Yet one exception instance may be identified in case of KSČM. Overall, the proportion of European themes keeps growing, albeit in a limited amount, and so does the level of criticism and negativism toward the institution. Other political parties do not emulate this type of unequivocal tendencies in regard to the share of European issues. Apart from minor exceptions, the amount of European issues has been growing as evidenced by the data and then shown in a long-term perspective. Nonetheless, the findings emphasizing the sequential growth of European themes contradict Kovář's expectations (2014) based on experience of Western member states.

European Parliament elections are not merely the second-order elections and thereby experiencing a lower turnout, but separate stances of political parties affect the final outcome of each election weightily. This attribute exacerbates the perception of the EU, and thus stimulates the "non-European" atmosphere which results in a spiral of misunderstandings in respect of the EU and its policies. Contrary to Nielsen and Franklin's 
conclusions (2017), however, stating that the 2014 EP election has produced a wave of Euroscepticism, apart from the ODS, Czech parties exhibited only a negligible accumulation of pessimism toward the EU, or alternatively, a continuous decline has even lingered on. This approach may be consequently termed as a "soft" Eurosceptic interpretation of politics (Riishøj, 2007, 352). And besides, in the Czech case, attitudes and stances, which political parties represent, are strongly conditioned by the voters interests of which cannot be found in the EU agenda (Hloušek, Pšeja, 2009). In conclusion, the question is whether the Czech political parties will be able to integrate and make use of Europeanism in the near future or whether the EP elections will remain abused for domestic political maneuvers about nothing truly European.

\section{REFERENCES}

AUERS, D. (2005). European elections in eight new member states. In: Electoral Studies, Vol. 24, No. 4, 2005, pp. 747-754.

BLONDEL, J., SINNOTT, R., SVENSSON, P. (1998). People and Parliament in the European Union: Participation, democracy, and legitimacy. Oxford: Oxford University Press, 1998, 308 pp.

DRISKO, J. W., MASCHI, T. (2015). Content analysis. Oxford: Oxford University Press, 2015, $208 \mathrm{pp}$.

EIBL, O. (2011). Politický prostor a témata v České republice v letech 20062008. Brno: Centrum pro studium demokracie a kultury, 2011, 213 pp.

EUROPEAN PARLIAMENT. (2018). European Parliament elections: Final scores of turnouts (1979-2014). [online]. Available at: <http://www. europarl.europa.eu/elections2014-results/en/turnout.html>. [Accessed 9 December 2018].

FEREBAUER, V. (2018). Vztah Čechů k EU za patnáct let ochladl. In: iDnes. [online]. Available at: <https://www.idnes.cz/zpravy/domaci/ vztah-cechu-k-evropske-unii-uprchlicka-krize-prijeti-do-eu-kritikaunie-lisabonska-smlouva.A180515_111811_domaci_fer>. [Accessed 9 December 2018].

HAVLÍK, V. (2009). České politické strany a evropská integrace: Evropeizace, evropanství, euroskepticismus? Brno: Mezinárodní politologický ústav, 2009, 200 pp.

HLOUŠEK, V., PŠEJA, P. (2009). Europeanization of political parties and the party system in the Czech Republic. In: Journal of Communist Studies and Transition Politics. Vol. 25, No. 4, 2009, pp. 513-539. 
HIX, S., NOURY, A. G., ROLAND, G. (2007). Democratic politics in the European Parliament. Cambridge: Cambridge University Press, 2007, 260 pp.

KOVÁ̌̆, J. (2014). Europeizace volebních programů pro volby do EP. In: Politické vedy. Vol. 17, No. 3, 2014, pp. 32-67.

KRIPPENDORFF, K. (2004). Content analysis: An introduction to its methodology. London: SAGE Publications, 20104, 472 pp.

LEŠKA, D. (2015). The Europeanization of Slovak political parties. In: Slovak Journal of Political Sciences. Vol. 15, No. 1, 2015, pp. 31-58.

LINEK, L., LYONS, P. (2014). Dočasná stabilita: Volební podpora politických stran v České republice v letech 1990-2010. Praha: SLON, 2014, 222 pp.

MANSFELDOVÁ, Z. (2003). Obsahová analýza volebních program českých politických stran. In: DVOŘÁKOVÁ, V., HEROUTOVÁ, A. (eds.). II. Kongres českých politologů, Praha: ČSPV, 2003, pp. 470-478.

MARINESCU, V., NOWAK-TETER, E., BRANEA, S., FOX, B., MERKOVITY, N., MIHÁLYFFY, Z., DEŽELAN, T., MAKSUTI, A. (2017). In search of common patterns: Political advertising in Central and Eastern Europe. In: HOLTZBACHA, C., NOVELLI, E., RAFTER, K. (eds.). Political advertising in the 2014 European Parliament elections, London: Palgrave Macmillan, 2017, pp. 135-152.

MARSH, M. (1998). Testing the second-order elections model after four European Elections. In: British Journal of Political Science. Vol. 28, No. 4, 1998, pp. 591-607.

MAŠKARINEC, P. (2017). The Czech Pirate Party in the 2010 and 2013 parliamentary elections and the 2014 European Parliament elections: Spatial analysis of voter support. In: Slovak Journal of Political Sciences. Vol. 17, No. 1, 2017, pp. 5-33.

NIELSEN, J. H., FRANKLIN, M. N. (2017). The Eurosceptic 2014 European Parliament elections. London: Palgrave Macmillan, 2017, 265 pp.

NORRIS, P. (1999). Recruitment into the European Parliament. In: KATZ, R. S., WESSELS, B. (eds.), The European Parliament, the national parliaments, and European integration. Oxford: Oxford University Press, 1999, pp. 86104.

PROCHÁZKOVÁ, I., HLOUŠEK, V. (2013). Významnost tématu evropské integrace: obsahová analýza programů českých stran pro parlamentní volby 2006 a 2010. In: Evropská volební studia. Vol. 8, No. 2, 2013, pp. 113-132.

REIFF, K., SMITT, N. H. (1980). Second-order national elections: A conceptual framework for the analysis of European election results. In: European Journal of Political Research. Vol. 8, No. 1, 1980, pp. 3-44. 
RIISHØJ, S. (2007). Europeanization and Euroscepticism: Experiences from Poland and the Czech Republic. In: Nationalities Papers. Vol. 35, No. 3, 2007, pp. 503-535.

RINGE, N. (2010). Who decides, and how? Preferences, uncertainty, and policy choice in the European Parliament. Oxford: Oxford University Press, 2010, 233 pp.

SOMER-TOPCU, Z., ZAR, M. E. (2014). European parliamentary elections and national party policy change. In: Comparative Political Studies. Vol. 47, No. 6, 2014, pp. 878-902.

STAVRIDIS, S., IRRERA, D. (2015). The European Parliament and its international relations. London: Routledge, 2015, 304 pp.

STOYANOV, D. (2017). Central and East European Euroscepticism in 2014: Domestic politics matters. In: NIELSEN, J. H., FRANKLIN, M. N. (eds.). The Eurosceptic 2014 European Parliament elections. London: Palgrave Macmillan, pp. 103-124.

ŠARADÍN, P. (2008). Teorie voleb druhého řádu a možnosti jejich aplikace $v$ České republice. Olomouc: Univerzita Palackého, 2008, 162 pp.

ŠIMUNJAK, M., MILANOVIĆ, L. (2017). The first time for everything: Political advertising in a new member state. In: HOLTZ-BACHA, C., NOVELLI, E., RAFTER, K. (eds.). Political Advertising in the 2014 European Parliament Elections. London: Palgrave Macmillan, 2017, pp. 153-168.

TERPAN, F., SAURUGGER, S. (2019). The CJEU and the Parliament's external powers since Lisbon: Judicial support to representative democracy? In: COSTA, 0. (ed.), The European Parliament in times of EU crisis: Dynamics and transformations, Cham: Palgrave Macmillan, 2019, pp. 77-98.

WEBER, R. P. (1990). Basic content analysis. London: SAGE Publications, 1990, 96 pp.

WERNER, A., LACEWELL, O., VOLKENS, A. (2011). Comparative Manifesto Project: Handbook of coding instructions, $4^{\text {th }}$ Edition. [online]. Available at: <https://manifesto-project.wzb.eu/down/papers/handbook_v4.pdf>. [Accessed 15 December 2018].

WRING, D., GRILL, C., MEKOVITY, N., DEACON, D. (2017). Populist politics and the 'radical right' in 2014 elections. In: HOLTZ-BACHA, C., NOVELLI, E., RAFTER, K. Political advertising in the 2014 European Parliament elections. London: Palgrave Macmillan, 2017, pp. 97-118.

\section{SCRUTINIZED ELECTION PROGRAMS}

ČSSD's EP election program (2004). Obtained from the ČSSD's Archive via: $<$ archiv@socdem.cz>. 
ČSSD's EP election program (2009). [online]. Available at: <http://www. evropskezpravy.cz/soubory/dokumenty/cssd-jistota-ep2009-917.pdf>. [Accessed 3 March 2017].

ČSSD's EP election program (2014). [online]. Available at: <http://www. cssd.cz/data/files/manifest.pdf>. [Accessed 3 March 2017].

ČSSD's EP election program (2019). [online]. Available at: <https://www. cssd.cz/data/files/volby-do-ep-argumentar.pdf>. [Accessed 24 March 2020].

KDU-ČSL's EP election program (2004). [online]. Available at: <http:// preview.kdu.cz/Dokumenty/Volby/2004/Volby-do-Evropskehoparlamentu/2004/Evropsky-volebni-program-KDU---CSL.aspx>. [Accessed 3 March 2017].

KDU- ČSL's EP election program (2009). [online]. Available at: <http:// www.roithova.cz/soubory/Volebni_program_KDU-CSL_do_EP_20092014.pdf?fid=1241961694>. [Accessed 3 March 2017].

KDU-ČSL's EP election program (2014). [online]. Available at: <http://www. volbydoep.cz/getmedia/b2402746-09d9-4fef-956f-aaff11b92712/ Europrogram_KDU_2014.pdf.aspx>. [Accessed 3 March 2017].

KDU-ČSL's EP election program (2019). [online]. Available at: <https://www. kdu.cz/aktualne/ruzne/program-kdu-csl-pro-volby-do-evropskehoparlamentu\#2>. [Accessed 24 March 2020].

KSČM's EP election program (2004). [online]. Available at: <https://www. kscm.cz/nasestrana/kscm-a-volby-dokumenty/volby-2004/evropskyparlament/28372>. [Accessed 3 March 2017].

KSČM's EP election program (2009). [online]. Available at: <https://www. kscm.cz/volby-a-akce/volby-do-ep-2009/volebni-program>. [Accessed 3 March 2017].

KSČM's EP election program (2014). [online]. Available at: <https://www. kscm.cz/volby-a-akce/evropsky-parlament2/program>. [Accessed 3 March 2017].

KSČM's EP election program (2019). [online]. Available at: <http://www. nenechmetotak.cz/katalog-obrazku/clanek-68/527-kscm-volebniprogram.pdf>. [Accessed 24 March 2020].

ODS's EP election program (2004). [online]. Available at: <http://www.ods. cz/docs/programy/program_2004e.pdf>. [Accessed 3 March 2017]. ODS's EP election program (2009). [online]. Available at: <http://www.ods. cz/docs/programy/program_2009ep.pdf $>$. [Accessed 3 March 2017]. ODS's EP election program (2014). [online]. Available at: <http://www.ods.cz/ docs/programy/program-volbyEP2014.pdf>. [Accessed 3 March 2017]. 
ODS's EP election program (2019). [online]. Available at: <http://zahradil. cz/wordpress/wp-content/uploads/2019/04/ODS_program_final.pdf>. [Accessed 24 March 2020]. 